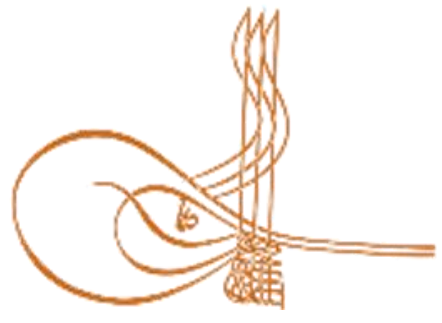

www.turkishstudies.net/social
Turkish Studies - Social Sciences

eISSN: $2667-5617$

Research Article / Araștırma Makalesi

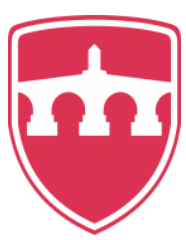

INTERNATIONAL

BALKAN

UNIVERSITY

Sponsored by IBU

\title{
Uluslararası Göç ve Kalkınma İlişsisinin Ekonomi Politiği
}

Political Economy of the Relationship Between International Migration and Economic Development

\author{
Ayşe Cebeci*
}

\begin{abstract}
There was a significant increase in illegal migration in the period from the 1970's to the present day. According to the United Nations Global Migration Database, the number of people migrating as refugees and asylum seekers in the period from 2010 to 2017 is approximately 13 million. Therefore, countries attach importance especially to the control and management of international migration. However, the control of international migration paved the way for the development of international management strategies for migration, going well beyond being structured at national level on the basis of political and economic interests of immigrant-receiving and immigrant-sending countries. "Migration and economic development" studies in this area occupied a special place. The relationship with economic development is established on the basis of both the aceeptance of immigrants by nationals of the receiving country and the contribution of immigrants to the capital accumulation in the receiving country. Particularly in terms of an argument of mainstream economics which asserts that "economic development can be achieved along with the increase in factors of production of the countries", immigrants are perceived as factors of production. On the other hand, in light of the assumption suggesting that "international migration would have positive effects also on the economic development of the sending country", the relationship between migration and economic development gave rise to the development of new policies. Assuming that migration studies are categorized under three basic approaches as Historical-Structural approach, Economic-Neoclassical approach and Migration Systems approach, this study which adopts a historical approach endeavors to analyze different needs and the transformation in migration policies which come into existence along with capital accumulation throughout the historical process. Nevertheless, in doing so, the analysis incorporates also the unique conditions of countries and implications of individual circumstances on migration policies, and thereby, goes beyond a structural mechanics approach.
\end{abstract}

\footnotetext{
* Dr. Öğr. Üyesi, Harran Üniversitesi, İİBF, İktisat Bölümü

Asst. Prof. Dr., Harran University, Faculty of Economics and Administrative Sciences, Department of Economics orcio 0000-0003-2973-2021

183171@gmail.com

Cite as/ Atıf: Cebeci, A. (2020). Uluslararası göç ve kalkınma ilişkisinin ekonomi politiği, Turkish Studies - Social, 15(2), 93-106. https://dx.doi.org/10.29228/TurkishStudies.40578

Received/Geliş: 15 January/Ocak 2020

Accepted/Kabul: 25 February/Şubat 2020

Copyright $(\mathcal{C}$ INTAC LTD, Turkey
} 
Structured Abstract: The study analyzes the transformation of policies developed for the management of international migration which grows at a raid rate and influences lives of millions of human beings as well as having effects on socio-economic structures of countries today. Especially the relationship between international migration and economic development was highlighted in studies performed by international organizations in recent years. However, the relationship between migration and economic development places the focus on the question as to "how the migration management should be conducted so that it would affect favorably the economic development of both immigrant-receiving and immigrant-sending countries". Thus, actors of the relationship between migration and economic development are defined at country level. On the other hand, neither each migrant is integrated to the societal structure under the same conditions in a class-based society, nor each country is at the same level of economic development/capital accumulation processes as other countries. For instance, societal relations and labor qualifications which are required by capital accumulation processes of developed (early capitalist) countries and developing (late capitalist) countries differ from each other. Besides, the ways through which these countries are integrated into the international capital markets and also their competitive powers are different. Therefore, distinct policies intended for different types of migration (regular/irregular, domestic/international) are developed. A country makes utmost effort to entirely ban the irregular migration whereas another country closes its eyes to the arrival of irregular migrants in its territory and even ignores it if irregular migrants are employed informally in its territory. This circumstance comes into play as a response to several factors such as the current state of labor market, labor qualifications demanded by sectors of the economy, and competitive power of sectors in both country types.

However, today, migration policy and its management are no longer addressed through a process created and managed individually by countries alone. Crucial efforts are made to institutionalize 'migration governance' particularly in the context of the topic of international migration, and countries playing an active role in these efforts are in general developed countries which are characterized as early capitalist nations. In a similar vein, countries which previously did not have a serious migration policy and institutions to be involved with migration management also take steps for making arrangements on international migration through institutional and legal regulations.

At this juncture, analyses of migration are carried out in light of its various aspects and dimensions by several disciplines. Assuming that migration studies are categorized under three basic approaches as Economic-Neoclassical analyses, Historical-Structural approach and Migration Systems approach, this study which adopts a historical approach endeavors to analyze different needs and the transformation in migration policies which come into existence along with capital accumulation throughout the historical process. Nevertheless, in doing so, the analysis incorporates also the unique conditions of countries and implications of individual circumstances on migration policies, and thereby, goes beyond a structural mechanics approach.

While performing the study, a categorization of studies in the literature especially on migration and migration policies was created. Subsequently, documents particularly the basic policy texts of the European Union (EU) and United Nations (UN) which were published for regulating the relationship of migration and economic development were reviewed. The reason for taking EU texts as the basis pertains to the fact that they are texts on which several countries forming the EU agree with respect to international migration. Hence, migration policies produced by the EU can be analyzed on the basis of the stage of capital accumulation of the EU which is composed of early capitalist nations. That is why, especially policy texts of the EU and UN laid the factual basis of this study.

Upon the review of EU's basic texts on migration, it was ascertained that attempts were made to establish a significant link especially between sustainable development and migration. As per this review, countries should manage the migration effectively so as to achieve in reaching sustainable development goals. For the migration management by active institutions, a two-pronged approach was put forward. Firstly, controlling and preventing fully the irregular or illegal migration which is also characterized as a security problem are targeted whereas, secondly, promoting the capacity building and ensuring the receipt of regular migrants each year are aimed. The facilitation of regular migration is proposed to these countries as early capitalist nations determinedly oppose the irregular migration. The policy text titled 'Migration and 2030 Agenda for Sustainable Development' enters into the picture as a document which will set forth the framework of institutional and legal arrangements to be made on the topic of migration. This document proposes the facilitation of regular, natural and safe migration in particular. The de-industrialization and decline in the number of jobs requiring unskilled labor force in early capitalist nations along with the

Turkish Studies - Social, 15(2) 
globalization are suggested as the most important reasons for adopting this position. In order to overcome the labor shortage in jobs requiring qualified and skilled labor, the management of regular migration becomes a matter of particular importance. Migrants received in this respect will be employed and offer a solution to demographic problems of the EU which is aging. As indicated in the study, the most significant reason urging the EU to create a regular migration policy pertains to the fact that the population of countries forming the EU steadily decreases. According to UN statistics, Europe's population growth rate which was $25 \%$ in 1900 is forecasted to go down to $4 \%$ in 2060. The decline in the population joining the labor force as well as the fall in the population growth rate and the aging of current population will have negative influence on the capital accumulation process in the EU. Therefore, strengthening the migration governance through the development of a regular migration policy comes into play as an obligation for the EU. In this regard, in order to entice the qualified migrants to the EU, efforts are made. The Blue Card practice was developed for this purpose.

Another finding of the study is that, for preventing the irregular migration, developing countries which are also called as late capitalist nations do not act as eagerly and consistently as early capitalist nations since developing countries continue to need both unskilled and skilled labor force on account of not completing their industrialization processes yet. However, upon the inquiry as to why they do not undertake regular migration policies just as early capitalist nations do, certain cases demonstrate that this situation arises from the fact that migrants coming to these countries illegally impose a smaller cost on employers as they do not have work permit and are employed informally. The bargaining power of informally employed migrants is not strong enough to demand for both better wages and working conditions. They run the risk of being confronted with several sanctions even ending up with deportation from the receiving country upon a complaint to be filed to authorities by their employers. Therefore, it is likely for late capitalist nations to be populated more densely by irregular migrants and employ a larger number of irregular migrants. In parallel to the level of capital accumulation in these countries, employment opportunities are present also for relatively unskilled migrants. Moreover, for the purpose of boosting the competitive power of sectors, eyes are closed to the informal employment of workers in a way likely to lower the labor cost in the economy. Hence, as migrant workers are employed without job security and at low wages, a downward pressure is imposed on wages of domestic workers in the same sector and this situation gives rise to a fall in the average wage level. That being the case, workers' share which is allocated from the value added obtained by employers from the production is reduced while the unpaid hour per labor is increased.

For all these reasons, migration policies do not in general function properly in late capitalist nations and institutional arrangements are not buttressed through sanctions. For instance, necessary controls are not imposed on sectors in which large numbers of illegal migrants are known to be employed and the fate of illegal migrants falls into employers' hands.

Another relationship between migration and the economic development of late capitalist nations pertains to migrant workers' remittances. Foreign currencies transferred by migrant workers to their origin countries reached significantly high levels. It is estimated that the amount of workers' remittances is much higher than it is declared through official records. As the entry of foreign currency in the form of remittances provides late capitalist nations with foreign currencies necessary for their industrialization, it is likely to contribute to the capital accumulation process in these nations. Therefore, it will not only enable early capitalist nations to make profits by creating effective demand by late capitalist nations for manufactured goods to be produced by early capitalist nations, but will also supply late capitalist nations with the initial capital.

Factual basis was narrowed down in line with limitations of the study, however, the evaluation of migration policies within the historical context of capital accumulation which is indicated in this study can also be undertaken through different countries that will set as examples.

Keywords: International Migration, Development, Migration Policies, Migration Management, Capital Accumulation

Öz: 1970'li yıllardan günümüze yasadışı göçte önemli boyutlarda artış olmuştur. Birleşmiş Milletler Küresel Göç verilerine göre 2010-2017 yılları arasında mülteci (refugee) ve sığınmacı (asylum seker) olarak göç edenlerin sayısı yaklaşık olarak 13 milyonu bulmuştur. Bu nedenle özellikle uluslararası göçün kontrolü ve yönetimi ülkeler tarafından önemsenmektedir. Ancak uluslararası göçün kontrolü, ulusal ölçekte (göç alan ve 
göç veren) ülkelerin siyasal ve ekonomik çıkarlarına bağlı olarak şekillenmekten öte, uluslararası göç yönetim stratejilerinin oluşturulmasına neden olmuştur. Bu alanda "göç ve kalkınma" çalışmaları özel bir yer teşkil etmiştir. Gerek göçmenlerin, göç alan toplumdaki bireyler tarafindan kabullenilmesi gerekse göçmenlerin sermaye birikimine katkıları açısından "kalkınma" kavramı ile ilişki kurulmaktadır. Özellikle ana akım iktisadın "ülkelerin faktör stoklarında artış sağlanarak büyümenin gerçekleştirilebileceği" tezinde göçmenler, bir üretim faktörü olarak görülmektedir. Diğer taraftan "uluslararası göçün, göç veren ülkelerin kalkınmasına da olumlu etkiler yaratacağı" varsayımıyla göç ve kalkınma ilişkisi yeni politikaların oluşturulmasına neden olmuştur. Göç çalışmaları temel üç yaklaşım altında toplanacak olursa, Tarihsel Yapısalcı Yaklaşım, Ekonomik-Neoklasik yaklaşım ve Göç Sistemleri yaklaşımı içerisinde bu çalışma tarihsel bir yaklaşım ile sermaye birikiminin tarihsel süreçte ortaya çıkan farklı ihtiyaçları ile göç politikalarındaki dönüşümü analiz etmeye çalışmaktadır. Ancak bunu yaparken yapısalcı mekanik bir yaklaşıma düşmekten öte ülkelerin özgün koşullarını ve münferit olayların da göç politikalarına yansımalarını analize dahil etmektedir.

Anahtar Kelimeler: Uluslararası Göç, Kalkınma, Göç Politikaları, Göç Yönetimi, Sermaye Birikimi

\section{Giriş}

Göç, gerek göç alan gerekse göç veren toplumlardaki milyonlarca insanın yaşamını doğrudan ve dolaylı olarak etkileyen çok yönlü ve çok boyutlu bir olgudur. Ortaya çıkan bu etkiler bazı aktörler için olumlu bazı aktörler içinse olumsuz sonuçlar doğurmaktadır. Dolayısıyla birçok aktörle birlikte çatışma ve uzlaşıyı içeren bu sürecin yönetilmesi önem kazanmaktadır. Bu nedenledir ki özelikle 1970'lerden sonra daha fazla artan uluslararası göçün yönetimi ülkeler açısından da önem arz etmektedir. Sermayenin uluslararasılaştığı, küreselleşmenin hız kazandığı bu dönemde uluslararası göç ülke içindeki göçlerden daha fazla önem kazanmaya başlamıştır. BM'in Eylül 2019 verilerine göre 2019 yılında uluslararası göç 272 milyon kişiye ulaşmıştır (www.un.org, 2019). Gerçekleşen uluslararası göçün büyük bir kısmını ise düzensiz göç ya da yasadışı göç olarak adlandırılan göçler oluşturmaktadır Gene BM verilerine göre 2010-2017 yılları arasında göç etmek zorunda kalan yani göç yönetim politikaları dışında kalan 13 milyon göçmen bulunmaktadır. Kontrol edilemeyen bu göçmenlerin, özellikle mülteci ve sığınmacı konumundakilerin göç alan ülkeye maliyetleri öngörülemeyen boyutlara çıkmaktadır. Bu konuda Türkiye'nin Körfez Savaş1 sırasında Irak'tan ve 2011 sonrasında Suriye'den gelen göçmenlerle ilgili karşılaştığı durum örnek olarak verilebilecektir. Ancak her iki örnek de zorunlu olarak yerinden edilmeyi içermektedir. Diğer bir göç ise daha iyi koşullarda yaşamak ya da daha fazla gelir elde edebilmek için başka ülkelere giden işgücü göçünü içermektedir. Özellikle petrol zengini körfez ülkelerine diğer Arap ülkelerinden ve Güneydoğu Asya ülkelerinden gerçekleşen göç de buna örnek verilebilmektedir.

Gelişmeler incelendiğinde günümüz itibariyle milyonlarca insanın hayatına etki eden göçün yönetilebilir olması ve göç politikalarının geliştirilmesi ülkeler açısından daha fazla önem arz etmektedir. Bu nedenle sadece ulusal ölçekte değil uluslararası boyutta göç yönetim stratejileri ve politikaları üretilmeye başlanmıştır. Ancak bu politikaların değerlendirilmesi, çatışma ve uzlaşının nası1 yönetildiği önemlidir. Başta Birleşmiş Milletler olmak üzere uluslararası örgütlerin geliştirdiği stratejiler göçün kayıtlı ve düzenli olarak gerçekleştirilmesi ve "kapasite yaratılarak" gerçekleştirilmesini önermektedir. Ve uluslararası göç çalışmalarının çoğu kalkınma ile göçün yakın ilişkisini kurmaktadır. Bu noktada iki önemli soru ortaya çıkmaktadır, birincisi göçün kapitalist toplumsal ilişkileri ve sermaye birikimini nasıl etkilediği ikincisi ise küreselleşmenin bu kadar hızlandığ 1 ve sermayenin dünyanın her yerine gidebildiği bir dönemde neden ülke ekonomilerinin kalkınması için göçmen emeğine ihtiyaç duyulduğudur. Bu nedenle öncelikle göç çalışmaları genel olarak sınıflandırılacak ardından göçün sermaye birikim sürecinin tarihselliği içerisinde nasıl dönüştüğü ve hangi aşamalarda nasıl katkılarda bulunduğu tespit edilecektir.

Turkish Studies - Social, 15(2) 
Ardından göç politikalarının bu işleyiş/oluşa hangi katkıları sağladığı belirtilerek çalışma tamamlanacaktır.

\section{Göç Literatürüne Genel Bakış}

Kısaca göç alanında yapılan çalışmalar değerlendirildiğinde üç ana yaklaşımın oluştuğu gözlemlenmektedir. Bunlardan ilki ve göçün kalkınma ile ilişkisini kuran yaklaşım ekonomik (Neoklasik) teori olarak adlandırılan yaklaşımdır. Neoklasik ekonomik yaklaşım, insanların nüfusun yoğun olduğu yerlerden seyrek yerlere göç etme eğilimini iş döngülerindeki dalgalanma ile ilişkilendirir (Castles ve Miller, 2008:31). Bu teoriler itme-çekme teorileri olarak da bilinirler. Göç veren yere ait olan itici faktörler olarak; düşük yaşam standartları, siyasal baskılar ve ekonomik firsat yoksunluğu gösterilir. Göç alan yere ait olan çekici faktörler olarak ise emeğe olan talep dolayısıyla yüksek ücretler, ekonomik firsatlar ve siyasal özgürlükler tanımlanır (Castles ve Miller, 2008:31) , (Cebeci, 2017). Bu yaklaşım özellikle göç olgusunu bireyin kayıp ve kazançlarını rasyonel olarak değerlendirebilen, klasik iktisadın tanımladığı homoeconomicus insan modelinin bir tercihi olarak ortaya çıktığını kabul eder. İtici ve çekici faktörler dışında kalan etkiler değerlendirmeye alınmaz. Bu nedenle tarihsellikten uzak olarak değerlendirilmiştir (Cebeci, 2017). Göçmenlerin geldikleri toplumda tutunabilmek ve başarılı olabilmek için çalışmaları yerel toplumdaki işçiler ile aralarında rekabetin olmasına neden olmaktadır. Bu nedenle göçmenler sadece ülke ekonomisine "olumlu katkıda bulunmaktadır" noktasından öteye taşınarak sınıf içi ve sınıflar arası çatışmaya ve rekabet sürecine etkileri de analiz edilmelidir.

Neoklasik-ekonomik yaklaşım dışındaki çalışmaların bir kısmı ise Tarihsel Yapısalcı yaklaşım olarak sınıflandırılmaktadır. Bu yaklaşıma göre göç, sermaye için bir çeşit ucuz emek hareketidir ve "zenginleri daha zengin yapmak için eşitsiz kalkınmanın ve yoksul ülkelerin kaynaklarının sömürülmesinin devamlılığını sağlar" (Castles ve Kosack, 1985, Cohen, 1987, Sassen, 1988). Bu grupta değerlendirilen Dünya Sistemi teorisine göre de "Göç üçüncü dünyanın birinci dünyaya bağımlı kalması, dünya ticaretinin ve çıkarların kontrol edilmesi açısından askeri tahakküm kadar önemliydi" (Castles ve Miller, 2008:35). Tarihsel yapısalcı olarak adlandırılan Marxist göç teorileri, bazı çalışmalarda indirgemecilikle eleştirilmekte ve göç politikalarındaki değişimi açıklayamadıkları ileri sürülmektedir (Cebeci, 2017). Göç politikalarındaki değişimi açıklama açısından değerlendirildiğinde Neo-klasik yaklaşım devletin rolünü ve önemini azaltmakla eleştirilirken "tarihsel-yapısalcı yaklaşım ise sermayenin çıkarlarını her şeyin belirleyeni olarak görüp söz konusu bireylerin ya da grupların eylem ve isteklerine yeterince ilgi göstermemekle eleştirilmiştir" (Castles ve Miller, 2008:35). Bu nedenledir ki Kalkınma ve Göç arasındaki ilişkilerin analiz edilmesinde uluslararası göç politikalarının ulusal düzeyde "bir ülkenin diğerini sömürdüğ̈̈” tesbitinin ötesine geçerek, sermayenin uluslararasılaştığ günümüzde uluslararası göç politikalarının nasıl analiz edildiğini belirlemek önemli olmaktadır.

Son olarak üçüncü yaklaşım ise Göç Sistemleri Teorisi olarak adlandırılan teorilerdir. Bu yaklaşım, bir göç sisteminin birden fazla ülke tarafindan oluşturulduğunu ve oluşturulan bu sistemin hem göçmen akışının amacının sorgulanması hem de söz konusu yerler arasındaki mikro ve makro bütün bağların araştırılmasını hedeflemektedir. Bu bağlar "devletlerin birbirleriyle ilişkileri, kitle kültürü bağlantıları, aile ve toplumsal ağlar" olarak sınıflandırılabilir (Fawcett ve Arnold, 1987:456-7). Teori, göçün çeşitli nedenlerle ülkeler arasında önceden var olan bağlar üzerinden ortaya çıktığını ileri sürmektedir. Ancak bazı analizlerde bu bağların neden kurulması gerektiğine dair bir ön aşamaya geçilmemektedir. Örneğin; herhangi bir olayın ortaya çıkarttığı bağ üzerinden göçün ortaya çıktığını ileri sürüldüğünde göçün kapitalist toplumsal ilişkilerle ve işleyiş/oluş ile bağının yeteri kadar kurulamadığı görülebilir. Zira göç sistemleri teorisi göçü etkileyen makro ve mikro yapıların birlikte ele alınması gerektiğini ileri sürerken makro yapılar olarak ekonomik sistemi, devletler arasında göçü düzenleyen kanun ve uygulamaları incelerken, mikro yapılar olarak da göçmenlerin, göç sürecinin yarattığı koşullar ve yerleşme sorunlarıyla ilgili olarak kendileri tarafindan geliştirilen enformel toplumsal ağlar incelenmektedir (Böhning, 1984; 
Cohen, 1987; Mitchell, 1989; Hollifeld, 2000). Ancak göçü ülkeler arasındaki önceden var olan bağlardan ötürü ortaya çıktığını ileri süren çalışmalar bu bağları göçün nedeni olarak gösterirken, nedenlerin nedeni olan kapitalist toplumsal üretim ilişkileri ile olan bağı yeteri kadar kuramamaktadır. Örneğin İngiltere'deki Hindistan, Pakistan ve Bangladeş göçünü İngiltere'nin Hint coğrafyasındaki sömürgeci varlığına bağlarken, Almanya'daki Türk nüfusu ise Almanya'nın 1960'lar ve 1970'lerdeki doğrudan emek talebinin sonucu (Castles ve Miller, 2008:36) olarak ifade etmektedir. Oysa Almanya'daki 1970'lerdeki emek talebi ne kadar sermaye birikiminin ihtiyaçları ile yakından ilişkiliyse süregelen zamanlarda Almanya'daki göçmenler içinde Türkiye kökenli işçilerin daha fazla olmasının nedenleri arasında Türk işçilerin kapitalist çalışma koşullarına uyumlu olması, üretkenlikleri ve niteliklerinin işin gerekliliklerine uygun olması da önemli bir gerekçedir. Türkiye'den devam etmekte olan göçün sadece Almanya'da daha önce var olan göçmen işçilere bağlanması yeterli bir analiz değildir. Bu nedenledir ki özellikle kapitalist toplumsal ilişkilerin tam anlamıyla kurulduğu ve sermaye birikiminin tahakkümünün sürdüğü toplumlarda göçün nedenlerini, sonuçlarını ve süreci düzenleyen göç politikalarının nedenlerini sermaye birikiminin tarihsel süreçte farklılaşan ihtiyaçlarından bağımsız olarak değerlendirmek analizin dar bir alanda sinırlı kalmasına neden olacaktır.

Temel olarak üç grupta topladığımız teoriler göçü, nedenlerini ve göç neticesinde ortaya çıkan değişimleri analiz etmektedirler. Ancak birçok çalışmanın ve göçle birlikte ortaya çıkan sorunların çözümü noktasında çalışan bürokratların temel sorunu göçü ve göç politikalarını dinamik bir süreç olarak görmemeleridir. Göçün dinamik ve sürekliliği olan bir süreç olması, ülkelerdeki sermaye birikiminin tarihsel süreçte ihtiyaçlarının değişmesi, göçe dair politikaların dönüşmesi hep birlikte ele alınmalıdır. Bu bağlamda göçmenlerin sermaye birikim sürecine eklemlenmeleri ve birikim sürecine etkileri de göçün ilerleyen dönemlerinde zaman içinde değişecektir.

\section{Uluslararası Göçün Ülkelerin Sermaye Birikimine Etki Mekanizmaları}

Uluslararası göç, bireysel olarak göçmenlerin hayatlarını önemli ölçüde etkilerken göçe konu ülkelerin hem toplumsal yapılarını hem de sermaye birikimlerini etkilemektedir. Bu etkiler göç alan ve göç veren ülkelerde farklı şekillerde ortaya çıktığı gibi, sermaye birikim süreçleri farklı aşamalarda olan (erken kapitalistleşmiş ve geç kapitalistleşmiş) ülkelerdeki etkileri de farklılaşmaktadır. Dolayısıyla ülkelerin geliştirdikleri ulusal göç politikaları da farklılaşmaktadır. Aynı zamanda ülkelerin kendilerine özgü tarihsel koşulları da ulusal göç politikalarını etkilemektedir. Örneğin İkinci Dünya Savaşı sonrasında Avrupa'daki birçok ülke savaş dolayısıyla kaybettikleri işgücünü yerine koyabilmek için ciddi oranda göçmen çekecek, serbestleştirici göç politikaları izlemişlerdir. Bu nedenle ilk olarak ülkelerin özgün koşulları dışında göçün sermaye birikimine hangi mekanizmalar aracılığıyla etki ettiğini açıklayarak kavramsal netleşmeyi sağlamak gerekmektedir. Böylece ulusal ve uluslararası göç politikalarının mantığını anlamak daha kolaylaşacaktır.

Öncelikle göç alan ülkelerdeki sermaye birikimine göçün etkileri değerlendirilmelidir. Göç alan ülkeler, genellikle çalışma olanaklarının, gelir elde etme ve yaşam standartlarının daha fazla olduğu ülkelerdir. Bu genelleme her göç hareketi için geçerli değildir. Zira savaş dolayısıyla ya da başka zorunluluklar nedeniyle göç edenlerin ilk amaçları güvenli bir bölgeye göç etmek/sığınmaktır. Ancak BM verilerine göre 2019 yılı itibariyle dünyadaki 272 milyon uluslararası göçmenin 82 milyonunu Avrupa, 59 milyonunu Kuzey Amerika, 49 milyonunu ise Kuzey Afrika ve Batı Asya barındırmaktadır (www.un.org, 2019). Bu da en çok uluslararası göçmenin bulunduğu bölgelerin genellikle erken kapitalistleşmiş ülkelerin olduğu coğrafyalar olduğunu doğrular niteliktedir. Kuzey Afrika ve Batı Asya'da göç aldıkları kaynak ülkeler ile kıyaslandığında uluslararası sermaye birikimine daha fazla eklemlenmiş, çalışma ve gelir elde etme imkanlarının daha fazla olduğu bölgelerdir. 
Erken kapitalistleşmiş, "kalkınmış" ülkeler için göçün bu ülkelerdeki sermaye birikimine etkisi ile henüz kalkınma sürecinde olan geç kapitalistleşmiş ülkelerdeki sermaye birikimine etkileri farklılaşmaktadır. Erken kapitalistleşmiş ülkeler, teknolojisi eskimiş malların üretimini ve emek yoğun sektörlerdeki üretimi doğrudan yabancı sermaye (FDI) ${ }^{1}$ yatırımları ile başka coğrafyalara taşıdıkları için bu ülkelerde genellikle daha yeni teknolojik bilgi ile donatılmış nitelikli ${ }^{2}$ emeğe ihtiyaç bulunmaktadır. Örneğin Sassen Küresel Şehirlerin Yükselişi ve Yeni İşgücü Talebi çalışmasında kalkınmış ülkelerdeki büyük şehirlerin rolünü "özel hizmetler ve üst düzey yönetim girdilerinin üreticisi ve ihracatçısı" olarak yoğunlaştığını belirterek ihtiyaç duyulan işgücünün niteliğinin de değiştiğini belirtmiştir (Sassen, 1988:126-170). Bu nedenle erken kapitalistleşmiş ülkeler ekonomideki sektörlerin ihtiyaçlarını göz önüne alarak gerekli nitelikler ile donatılmış olan göçmenleri kabul etmeye çalışmaktadırlar. ${ }^{3}$ Erken Kapitalistleşmiş Ülkelerin yasa dış1 göçü engelleyerek, düzenli göçmen kabul etmeye yönelik politikalar geliştirmelerinin en önemli nedeni de budur. Zira bu ülkelerde niteliksiz işgücünü istihdam olanakları o kadar da fazla değildir. Düzenli göç ile göçmenlerin ülkedeki kalış süreleri, çalışma imkanları ve uyum süreçleri ilgili kurum ve kuruluşlar tarafından yönetilmektedir. Böylece göçün ortaya çıkarttığı (çatışma ve uyum) sürecin devletlere yükledikleri maliyet de azalmaktadır.

Göç alan kalkınmakta olan ülkelerde ise göç daha çok yasadışı şekilde gerçekleşmektedir. Bunun temel nedenlerinden biri ise ülkelerdeki çalışma izni için ödenen bedellerin yüksek olmasından kaynaklanmaktadır. Bir diğer neden ise göçmenlerin kayıt dışı çalıştırılması halinde işveren sigorta prim payı, tazminat ödemesi ya da asgari ücret düzeyinde ödeme yapılması gibi maliyet arttırıcı etkilerden kaynaklanmaktadır. Zira kayıt dışı çalışan "kaçak göçmen" her türlü korunmadan mahrumdur ve işverenin şikayet etmesi durumunda sınır dışı edilmeye kadar gidebilecek bir dizi yaptıım ile karșılaşabilecektir. Dolayısıyla çalışma izni ile yasal koşullara uygun olarak "düzenli göç" edilmesi halinde göçmen işçinin işveren ile ücret ve çalışma koşullarına dair pazarlık yapma gücü olabilecektir. Oysa yasadışı yollardan gerçekleşen "düzensiz göç" ile ülkeye gelen göçmen, işgücünü satarken çalışma koşullarına dair pazarlık yapma gücüne sahip değildir. $\mathrm{Bu}$ durum göçmenlerin doğrudan ucuz emek gücü olarak istihdam edilmeleri ile sermaye birikimini arttırıcı etki yaparken yerli işgücü üzerinde de dolaylı etkisi bulunmaktadır.

Göçmenler geldikleri ülkedeki işgücü piyasasında nicelik olarak işçilerin artmasını sağlayarak daha uzun saatler daha düşük ücretlerle çalışmayı kabul etmektedirler. Bu da yerli işgücü üzerinde baskı oluşturarak, işlerini kaybetmemek için daha uzun saatler daha düşük ücretler karşılığ 1 çalışmalarına neden olmaktadır. Böylece kalkınmakta olan ülkelerde karşılığ ödenmemiş emek zamanı arttırılarak, artı-değerden sermayenin aldığı pay arttırılmaktadır. Bu durumda sermaye birikimi arttığı gibi göçmen işçi çalıştırılan sektörlerin rekabet gücünün arttı̆̆ da gözlemlenmektedir. Örneğin; 2017 yılında Şanlıurfa'da işverenlerle gerçekleştirilen görüşmelerde Suriyeli göçmenler olmasaydı sektörün zora düşeceği ve üretimden çekilmek zorunda kalacakları belirttikleri görülmektedir. Gene 2018 yılı Mart ayında Hatay’daki ayakkabıcılık sektöründe

\footnotetext{
1 Küresel düzeyde sermayenin uluslararasılaşmasının/küreselleşmenin, üretim sistemlerindeki bölünme, lojistik imkanların artması, ana ülkeye kar transferinin serbestleştirilmesine yönelik düzenlemelerin gerçekleştirilmesi gibi gelişmeler ile çeşitli üretim süreçlerinin EKÜ'lerden daha düşük maliyetlerle üretim yapılabilen GKÜ'lere taşınması da EKÜ’lerin talep ettiği göçmenlerin niteliğini değiştirmiştir.

2 Bu noktada nitelikli ve niteliksiz tanımlamalarına dair bir tartışma yürütmek de gerekmektedir. Zira üretim sürecinde teknolojinin hızla değişmesi yeni teknolojilere dayalı olarak yeni üretim tekniklerinin üretim süreçlerine dahil olması dünün nitelikli işgücünü bugünün niteliksiz işgücü haline getirmektedir. Bu nedenledir ki hizmet içi eğitim, hayat boyu öğrenme gibi sürekli değișen, yenilenen niteliklerle donatılmayı içeren eğitim programları geliştirilmektedir. Dolayısıyla EKÜ'in bugün için nitelikli olarak tanımladıkları ve ihtiyaç duydukları bir işgücü birkaç sene sonra gerek üretim teknolojilerinin değişmesi gerek eskiyen teknolojiye dayalı üretim tesislerinin doğrudan yabancı yatırım (FDI) olarak başka ülkelere gitmeleri nedeniyle niteliksiz işgücü haline gelebilmektedir. Böylece dışarıdan kabul edilecek olan göçmen işgücünün nitelikleri de değişmek durumundadır.

3 Ancak her halükarda niteliksiz işlerde çalışmaya niyetli olan ciddi miktarda işgücünün de piyasada bulunması gerekmektedir. Böylece bu işkollarında ödenen ücret de baskılanabilecektir.
} 
faaliyet gösteren işveren ve işçilerle yapılan görüşmelerde Suriyeli göçmen işçilerin aylık 800 TL'ye çalışmayı kabul etmeleri neticesinde yerli işçilerin de işlerini kaybetmemek için 800 TL'ye çalışmayı kabul ettikleri tespit edilmiştir. İşverenler ayakkabı başına 1,5 TL. kazançları olduğunu dolayısıyla işçileri bu ücretlerle çalıştırmak zorunda olduklarını belirtmişlerdir. ${ }^{4}$ Böylece sermayedarlar istedikleri miktarda ucuz işgücüne ulaşarak rekabet güçlerini arttırırken sermayenin döngüsünde biçimsel dönüşüm aşamasında gerek duyulan bol ve ucuz emek gücü elde edilmiş olmaktadir.

Kalkınmakta olan ülkeler için göçün ikinci etkisi ise göçmenlerin sermayenin döngüsünde realizasyon aşamasında üretilmiş malların tüketicisi olarak katkı sağlamalarıdır. Özellikle ciddi boyutlarda göç alan ülkelerde, göçmenler sermaye birikimi sürecinde realizasyon aşamasında efektif talep olarak birikim sürecine katkı sağlamaktadırlar. Bu etki kendi yerel nüfusu az olan ülkelerde daha fazla görülmektedir. Örneğin Arap ülkelerinden bazılarında göçmen nüfus yerli nüfusun üç katına ulaşmaktadır. Bu nedenle piyasadaki mallara olan talebin büyük kısmı göçmenler tarafından oluşturulmaktadır. Yerli nüfusu az olmasa da göçmen sayısının üç milyonun üzerinde olduğu Türkiye gibi ülkelerde de gene göçmenlerin hayatlarını idame ettirmek için gerek duydukları malların talebinde ciddi bir artış olduğu gözlemlenmektedir.

Göçün sermaye birikimine bir diğer etki mekanizması ise göçmen döviz transferleri (remittances) dir. Özellikle göç veren kalkınmakta olan ülkelerde ciddi boyutlara ulaşan göçmen döviz transferleri önemli boyutlara ulaşmaktadır. 2020 Dünya Göç Raporu'nun verilerine göre 2018 yılında uluslararası transfer edilen göçmen dövizleri toplamı 689 milyon dolara ulaşmıştır (IOM, 2019). Bu transferler içerisinde ilk üç havale alıcısını 78,6 milyon dolar ile Hindistan, 67,4 milyon dolar ile Çin ve 35,7 milyon dolar işe Meksika oluşturmaktadır. Döviz formundaki bu transferler birikim sürecinde iki aşamada etki sağlamaktadır. Birincisi döviz transferini alan ülkede gelirleri arttırdığı için mamul mallara talebi arttırarak realizasyon aşamasında birikim sürecine katkı sağlamaktadır. İkincisi ise bu ülkelerin kalkınma sürecinde ihtiyaç duyulan yatırımlar için makine /teçhizat gibi malların yurt dışından ithalatı için gerekli olan döviz sermaye ihtiyacını gidererek katkı sunmaktadır. Dolayısıyla göç birçok çalışmada üzerinde durulduğu gibi sadece ucuz işgücü açısından sermaye birikim mekanizmasına katkı sunmamakta realizasyon ve yeni yatırımların finansmanı noktasında ilk girişimci sermayesi açısından da önemli etkileri olmaktadır.

\section{Modern Zamanlarda Göç Politikalarında Değişim}

Tarihsel süreçte göç politikalarındaki değişimin incelenmesi Coğrafi Keşifler ve sonrasında göçlerin arttı̆g 1 döneme kadar incelenebilir. Bu dönemde Avrupa'dan Amerika'ya, Afrika'dan Avrupa'ya ve Kıta içinde birçok göç oluşmuş ${ }^{5}$ ve bu göçlere yönelik olarak da farklı politikalar ve düzenlemeler oluşturulmuştur. Ancak çalışmanın kısıtları çerçevesinde 1970’lerden sonra Avrupa'da göç politikalarında gözlenen dönüşüm analiz edilmiştir.

1970’lere kadar Batı Avrupa'da göç olumlu karşılanırken günümüzde göçe ve göçmenlere olumsuz yaklaşımlar giderek artmıştır. Bu tespit göç alanında ortaya koyulan birçok çalışmada görülebilmektedir. Göçe yönelik olarak ortaya çıkan bu hoşnutsuzluğun arkasında çeşitli nedenler gösterilmiştir. Bunların bir kısmı göçmenlerin karıştığı kriminal olayların artması, terör saldırılarında göçmenlerin yer alması gibi nedenlere dayandırılmaktadır. Kuşkusuz 11 Eylül 2001 İkiz Kuleler saldırısının ardından da göçmenlere yönelik korkunun arttığı ve göçün, ulusal, kültürel ve toplumsal güvenliği tehdit ettiği algısı hızla yayılmıştır (A. Kaya, 2016:232). Bu algının yaygınlaşmasında 2004 Lahey Programında göçün güvenlik tehdidi olarak algılanması ve 'yasadışı

\footnotetext{
4 “Suriyeli Göçmenlerin İşgücü Piyasasına Etkileri” başlıklı Harran Üniversitesi Bilimsel Araştırma Projesi kapsamında gerçekleştirilen saha görüşmelerinden elde edilen bilgilerdir.

5 Örneğin; Avrupalılar geçici ya da kalıcı bir şekilde farklı kıtalara denizci, asker, tüccar, idareci ve rahip olarak göç etmişlerdir. 17. ve 18. yy.larda Hollanda Doğu Hindistan şirketinin denizcilerinin ve askerlerinin yarısı Almanya'nın fakir bölgelerinden gelen Hollandalı olmayan göçmenlerden oluştuğu belirtilmektedir (Castles ve Miller, 2008:72).
} 
göçlerin' veya mültecilerin AB'ye gelmek için kullandığı yolları gösteren haritaların, $A B$ vatandaşlarının gözünde Avrupa'nın 'Üçüncü Dünya'nın' istilasından kurtarılması gereken bir toprak parçasına dönüşmesine katkıda bulunan ideolojik birer metin haline gelmeleri de bulunmaktadır (A.Kaya2016:233). Ancak göçe yönelik algının farklılaşmasının nedenlerinden birinin de, EKÜ'lerdeki sermaye birikiminin ihtiyaçlarının farklılaşması olduğunu belirtmek gerekmektedir. Özellikle küreselleşme sürecinde üretken sermayenin uluslararasılaşması neticesinde (sanayisizleşme) fabrikaların GKÜ'lere taşınması ve mevcut tesislerde üretimde sermaye yoğunluğunun artması (makineleşme) dolayısıyla işsizliğin artması özellikle niteliksiz göçmen emeğine ihtiyacı ortadan kaldırmıştır. Mevcut işler için yeterince eğitimli ve kalifiye olmayan göçmenler arasında işsizlik ve yoksulluğun yaygınlaşması ile dışlanma ve şiddet gibi sorunların da ortaya çıktığı görülmüştür.

Aynı zamanda 1989'da Doğu Bloku'nun çökmesi ile ortaya çıkan siyasi istikrarsılılılar ve etnik çatışmalar dolayısıyla bu ülkelerden akraba ve soy birlikteliği yaşadıkları diğer Avrupa ülkelerine önemli boyutta göçler ortaya çıkmıştır. Avrupa ülkeleri 1990'larda gerçekleşen bu yeni göçmenleri sindirmek için hazırlıklı değildi. Bu demografik değişim kültürel çatışma ve korkuyu da beslemiştir. $\mathrm{Bu}$ nedenle erken kapitalistleşmiş Batı Avrupa ülkelerinde göç ve entegrasyon politikaları giderek sertleşmeye başlamıştır. Ayrıca 11 Eylül New York, 11 Mart Madrid ve 7 Temmuz Londra saldırıları sonrası da göç politikalarında önemli kısıtlamalara gidilmiştir.

Görülmektedir ki gerek münferit olaylar gerekse tarihsel süreçte sermaye birikiminin ihtiyaçlarının farklılaşması dolayısıyla göçmenlere yönelik algının değişimi ve buna bağlı olarak da göç politikalarında değişim ortaya çıkmıştır. Bu değişim aynı zamanda göç politikalarının ulusal politik ve ekonomik çıkarlardan öte uluslararası ya da daha çok kullanılan söylemle "göçe yönelik küresel yaklaşım” çerçevesinde şekillendirilmeye başlamıştır. Göçe yönelik küresel yaklaşım çalışmaları ülkelerin göç politikalarının uyumlulaştırılmasını da hedeflemektedir. Bu bağlamda AB'nin göç politikalarındaki değişimin politika metinleri üzerinden değerlendirilmesi AB'nin sermaye birikim sürecinde değişen ihtiyaçların etkisini değerlendirmeye de izin verecektir.

Daha önce de belirtildiği üzere EKÜ’lerde gerek küreselleşme, sanayisizleşme gerekse terör olaylarındaki artış dolayısıyla 2000'lerde göçmenlere yönelik olumsuz algı göç politikalarının sertleşmesine neden olmuştu. Ancak AB'nin göçmenlere kapılarını kapatma ve hiçbir şekilde göçmen kabul etmeme gibi bir yaklaşımı benimsemesi pek mümkün gözükmemektedir. AB'ni düzenli göç politikası oluşturmaya iten önemli gerekçeleri bulunmaktadır. Bunlardan en önemlisi Birliği oluşturan ülkelerin nüfusunun giderek azalmakta olmasıdır. Birleşmiş Milletler verilerine göre 1900'de nüfus artış hızı \%25 olan Avrupa'nın 2060 yılında nüfus artış hızı \%4 seviyelerine inmesi beklenmektedir. ${ }^{6}$ Nüfus artış hızının azalması ve mevcut nüfusun yaşlanmasıyla işgücüne katılan nüfusun azalması da ortaya çıkmaktadır. İşgücünde ortaya çıkacak olan açı̆̆ın düzenli bir göç politikası ile desteklenmemesi durumunda, yaşlanan nüfus dolayısıyla sosyal güvenlik giderlerinin artmasina ve AB'nin sermaye birikimine olumsuz etkide bulunacağı beklenmektedir. AB İstatistik Kurumunun (Eurostat) verilerine göre 2060 yılında $A B$ ülkelerindeki çalışan göçmen işçiler dikkate alınmadığında 2060 yılında çalışan nüfus sayısı 110 milyon kişi daha az olacaktır. Günümüzde 65 yaşın üzerindeki her kişi için çalışma çağında dört kişi bulunurken bu sayının 2060 yılında iki kişiye düşeceği beklenmektedir. ${ }^{7} \mathrm{Bu}$ nedenledir ki AB'nin mevcut sermaye birikimini sürdürmesi ve birliğin finansmanı için geliştirilecek göç politikaları ve göçün yönetimi büyük önem taşımaktadır.

Avrupa'da göç konusunda uluslararası ilk işbirliği 1985 yılında kabul edilen ve 1995 yılında yürürlüğe giren Schengen Anlaşmasıdır. Bu anlaşma ile Schengen bölgesi olarak kabul edilen alanda iç sınır kontrolleri kaldırılarak dış sınır kontrollerinin güçlendirilmesi yönünde

\footnotetext{
${ }^{6}$ UN Statistical Division and Eurostat, EU27.

7 "Immigration in the EU", Eurostat, (05.12.2019).
} 
düzenlemelere gidilmiştir. Böylece AB'yi oluşturan ülkeler içinde göç serbestleştirilirken üçüncü ülkelerden gelecek olan göçmenler için sıkı kontroller devreye girmiştir. 1993'de yürürlüğe giren Maastricht Antlaşmasında göç ve sığınma adalet ve içişleri alanına alınarak 1999'da Amsterdam Antlaşması ile de AB Antlaşmasına dahil edilmiştir. Böylece ülkelerin bağımsız göç politikaları ve göç yönetimi oluşturmaları gibi bir alternatif ortadan kalkmıştır.

2000’li yıllarla birlikte özellikle birlik dışından gelen göçmenlere yönelik alınacak kararlar ve düzenlemeler birliğin tek taraflı uygulamaları ile sağlanamayacağı anlaşıldığında 13 Aralık 2005'de kabul edilen "Göçe Yönelik Küresel Yaklaşım” ile kaynak ve transit ülkelerin de göç politikalarına ve göçün yönetimine dahil edilmesi hedeflenmiştir Böylece transit ve kaynak ülkeler ile kapsamlı ve dengeli bir ortaklık kurularak göç, dış ilişkiler ve kalkınma politikaları bir araya getirilmiştir (Samur, 2008:8). Göç yönetiminde Birlik dışındaki ülkeler ile işbirliğinin öneminin anlaşılmasıyla 2011 yılında "Göç ve Hareketliliğe İlişkin Küresel Yaklaşım” kabul edilerek, düzensiz göç ve kaçakçılıkla mücadelenin arttırılması bunun yerine düzenli göçün kolaylaştırılmasına yönelik düzenlemeler yapılması kararı alınmıştır. ${ }^{8}$

"Coğrafi Denge" başlığı altında farklı kıtalardan farklı ülkeler ile Ortaklıklar oluşturulmuştur. Göç politikasına dair alınan kararlar "Hareketlilik Ortağı" (Mobility Partnership) olarak tanımlanan ülkeler ile de imzalanarak düzenlemelerin hayata geçmesi sağlanmıştır. AB hareketlilik ortaklarına düzensiz göçle mücadele etmeleri karşılığında düzenli göç olanakları sunmaktadır.

13 Mayıs 2015'de ise özellikle “Arap Baharı”nın yaşandığ 1 ülkelerden ve Suriye'den AB'ye gelecek olan yeni göç akınları için “Göçe İlişkin Avrupa Gündemi” başlığı ile acil eylem planı oluşturulmuştur. ${ }^{9} \mathrm{Bu}$ politika metninde uzun dönemde göçe ilişkin olarak benimsenecek temel yaklaşım üç madde ile belirtilmektedir:

* Kalifiye / nitelikli göçmenlerin çalışma izinlerinin kolaylaştırılması için Mavi Kart uygulamasının aktifleştirilmesi

* Göçmenlerin işgücü piyasasına erişiminin arttırılması

* Kaynak ülkelerin kalkınmasına destek sağlanarak düzensiz göçün azaltılması

Böylece AB'nin düzensiz göç ile yaptığı mücadelede EKÜ'lerin kalkınma süreçlerinin desteklenmesi de politika metninde yer bulmuştur. Türkiye'deki Suriyeli göçmenlerin mesleki eğitim alarak işgücüne dahil olmaları için BM'nin finanse ettiği mesleki eğitimler de bu bağlamda değerlendirilebilecektir.

Son olarak uluslararası göçün yönetimine dair geliştirilen en önemli politika metni BM tarafından oluşturulan "Migration and 2030 Agenda for Sustainable Development" çalışmasıdır. Rapora göre göçmenler dünya nüfusunun yüzde üçünü oluştururken göçmen işçiler dünya GSYIH'sının yüzde dokuzundan fazlasını üretmektedir (UN,2019) ${ }^{10}$. BM'in Göç ve 2030 Gündemi raporunda göç ve kalkınma arasındaki ilişki olumlanırken göç yönetiminin önemi öne çıkartılmaktadır. Göçmenler hem göç ettikleri ülkedeki işgücü piyasasına nitelik ve farklı özellikler getirerek güçlendirirken, kaynak ülkelere de yeni bilgiler ve finansal kaynak aktararak kalkınmalarına destek olmaktadırlar ancak göçün yönetimi başarısız olursa maliyetler artacak ve kalkınma süreci olumsuz etkilenecektir (UN,2019).

\footnotetext{
8 Ayrıntılı bilgi için bknz: European Commission, "Global Approach to Migration and Mobility", http://ec.europa.eu/home-affairs/what-we-do/policies/international-affairs/global-approach-to-migration. (e.t. 12.12.2019) ${ }^{9}$ Ayrıntılı bilgi için bknz: European Commission, "European Agenda on Migration”, http://ec.europa.eu/home-affairs/what-we-de/policies/european-agenda-migration_en (e.t. 05.01.2020) ${ }_{10}$ Ayrıntılı bilgi için bknz: http://unitedkingdom.iom.int/sites/default/files/oublication/Migration-and-the\%20-2030Agenda.pdf
} 
$\mathrm{Bu}$ raporda belirtilen en önemli yaklaşım değişimlerinden birisi AB'nin de benimsediği gibi göçün yönetiminde hedef, kaynak ve transit ülke kavramlaştırmalarının ötesine geçerek, göçün uluslararası yönetişiminde küresel partnerler olarak yer alınması gerektiğidir. Böylece ulusal pozisyonların ötesinde küresel bir yaklaşım geliştirilerek tüm ülkelerin geliştirilen genel stratejiye uygun şekilde yönetişim sürecine dahil olmaları hedeflenmektedir. 2030 Sürdürülebilir Kalkınma Hedefleri ile göç yönetimi arasındaki ilişki aşağıdaki tablo ile ortaya koyulmuştur.

Tablo 1: Sürdürülebilir Kalkınma Hedefleri ile Göç Arasındaki İlişki

\begin{tabular}{|c|c|}
\hline $\begin{array}{c}\text { Öğrenci } \\
\text { Hareketliliği }\end{array}$ & *Uluslararası Öğrenci Hareketliliăini Arttırma \\
\hline \multirow{3}{*}{$\begin{array}{c}\text { İnsan Ticareti ve } \\
\text { İstismarı }\end{array}$} & *Her Türlü İnsan Ticareti ve Sömürüsü İle \\
\hline & Mücadele \\
\hline & $\begin{array}{l}\text { *Kadın ve çocukların istismarının ve } \\
\text { ticaretinin ele alınması }\end{array}$ \\
\hline \multirow{5}{*}{$\begin{array}{c}\text { Emek Göçü ve } \\
\text { İstihdamı }\end{array}$} & *İnsana Yakışır İşi Teşvik Etmek \\
\hline & *Çocuk İşçiliği ile Mücadele \\
\hline & $\begin{array}{l}\text { *Zorla Çalıştırma için insan ticareti ile } \\
\text { mücadele }\end{array}$ \\
\hline & *Göçün Dişileştirilmesi \\
\hline & *İşgücü Göçü Yönetişiminin Geliştirilmesi \\
\hline \multirow[t]{3}{*}{ Göç Yönetişimi } & *Düzenli, olağan, güvenli göç ve \\
\hline & hareketliliğin kolaylaştırılması \\
\hline & $\begin{array}{l}\text { *Planlı ve iyi yönetilen göç politikalarının } \\
\text { uygulanması }\end{array}$ \\
\hline Göçmen Dövizleri & *Havale İşlem Maliyetlerini Düşürme \\
\hline Göç Verileri & $\begin{array}{l}\text { *Göç konusundaki verilerin iyileştirilmesi } \\
\text { *Göçün Durumuna Göre Verilerin } \\
\text { Ayrıștırılması }\end{array}$ \\
\hline
\end{tabular}

Görülmektedir ki AB'nin ve BM'nin önerdiği küresel göç politikası, göçün maliyetinin uluslararası düzeyde paylaşılmasını ancak göçün katkılarının da düzenli göç politikası ile Birliğin birikim sürecini geliştirecek şekilde yönetilmesini hedeflemektedir. Birlik, sermaye birikim sürecinin ihtiyaçları bağlamında gerek duyulan kalifiye/nitelikli göçmeni kabul ederken, birikim sürecinde değerlendiremeyeceği ve bu nedenle de Birlik üyesi devletlere maliyeti olacak olan niteliksiz göçmenleri Birlik dışında tutmayı hedeflemektedir. Çeşitli yollarda Birlik sınırlarını geçerek gelen düzensiz göçmeni ise "Geri Kabul Anlaşmaları" ile transit ve kaynak ülkelere iade etme yönünde politikalar geliştirerek bu göçmenlerin oluşturacağı yükten kurtulmaktadır.

\section{Sonuç Yerine}

Günümüzde göç politikası ve yönetimi ülkelerin tek başlarına oluşturdukları ve yönettikleri bir süreç olmaktan çıkmıştır. Özellikle uluslararası göç konusunda "göç yönetişimi" oluşturulmaya yönelik önemli çalışmalar yapılmaktadır. Bu çalışmalarda göç ve kalkınma arasındaki ilişki özellikle vurgulanmaktadır. Kalkınma kavramı hem göçle ilgili düzenlemelerin kabul edilebilirliğini ve meşruluğunu arttırmaktadır hem de göçmenlerin yerli halk tarafından kabul edilebilirliğini sağlamaktadır. Zira tüm ülkeler kalkınmaya pozitif bir anlam atfetmektedir. Bu nedenle güncel çalışmalar iyi yönetilen göç sürecinin hem EKÜ'lerde hem de GKÜ’lerde kalkınma sürecine olumlu katkı sağlayacağını belirtmektedir. 
$\mathrm{Bu}$ bağlamda literatürdeki birçok çalışma göçmenlerin göç ettikleri ülkedeki işverenlere ucuz işgücü sağlayarak sermaye birikimine ve kalkınma sürecine katkıda bulunduğunu belirtmektedir. Bu tespit özellikle sanayileşme sürecini yaşamakta olan ve her nitelikte işgücü açığ1 olan ülkeler için açıklayıcılığı olan bir tespittir. Ancak çalışmanın temel sorularından biri de küreselleşmenin bu kadar çok arttığı üretken sermayenin FDI aracıllğıyla uluslararasılaştığı bir dönemde EKÜ'lerdeki sanayisizleşme ve makineleşme dolayısıyla işsizlik artarken, nasıl olup da sermaye birikimi ve göç arasında bir bağ kurulduğudur. Yani bir işletme ucuz işgücü elde etmek istiyorsa vergilerin daha düşük olduğu, çevre düzenlemelerinin daha az olduğu, işgücü maliyetlerinin daha az olduğu ülkelere üretim tesisini taşıyabilirken, göç nasıl oluyor da EKÜ'lerin sermaye birikimine katkıda bulunmaktadır? Bu soruya cevap verilmesi için statik bir analizden öte göç politikalarındaki değişim EKÜ ve GKÜ'lerin sermaye birikim süreçlerinin geldiği aşama itibariyle farklılaşan ihtiyaçları ile analiz edilmesi gerekmektedir. Çalışmada bu çaba ülkelerin özgün koşullarını ve münferit olayların göç politikalarına yansımalarını göz ardı edilmeden sürdürülmüştür. Sermaye birikim sürecinin farklılıkları tanımlanırken ülkelerin uluslararası (küresel) birikim sürecine eklemlenme şekillerinin ve tarihlerinin farklılaşması nedeniyle EKÜ’ler ve GKÜ'lerin farklı nitelikteki işgücüne ihtiyaç duydukları tespitinden hareketle her iki ülke grubunun farklı göç politikalarını benimsedikleri görülmektedir.

Göç politikalarındaki dönüşümü analiz etmek için AB'nin ve BM'nin göçe yönelik politika metinleri incelendiğinde EKÜ'lerin düzensiz göçün önlenmesi için kısıtlayıcı düzenlemeler talep ederken, düzenli göçün ise kolaylaştırılmasına yönelik düzenlemeleri destekledikleri görülmektedir. Düzenli göçün kolaylaştırılmasında en önemli neden ise AB'yi oluşturan ülkelerin nüfusunun giderek azalmakta olmasıdır. Birleșmiș Miletler verilerine göre 1900'de nüfus artıș hızı $\% 25$ olan Avrupa'nın 2060 yılında nüfus artıs hızı \%4 seviyelerine inmesi beklenmektedir. Nüfus artış hızının azalması ve mevcut nüfusun yaşlanmasıyla işgücüne katılan nüfusun azalması da Birliğin sermaye birikim sürecine olumsuz etkide bulunacaktır. Bu nedenle AB'nin düzenli göç politikası oluşturarak göç yönetişimini güçlendirmesi bir zorunluluk olarak ortaya çıkmaktadır. Zira gerekli kalifiye göçmenleri Birliğe çekebilmek için çalışmalar yapılmaktadır.

Çalışmanın bir diğer tepiti GKÜ’lerin düzensiz göçü engelleme noktasında EKÜ’ler kadar istekli ve tutarlı olmadıklarıdır. Zira bu ülkeler sanayileşme süreçlerini tamamlamamış olduklarından hem niteliksiz hem de nitelikli işgücüne ihtiyaçları devam etmektedir. Ancak bu ihtiyacı neden EKÜ'lerdeki gibi düzenli göç politikasıyla gerçekleştirmedikleri sorusuna cevap arandığında karşılaşılan örnekler genellikle bu ülkelere kaçak olarak gelen göçmenlerin çalışma izinleri olmadığı için kayıt dışı çalışmaları dolayısıyla işverene maliyetlerinin düşük olmasından kaynaklanmaktadır. Zira kayıt dışı çalışan göçmenlerin gerek talep edecekleri ücret konusunda gerekse çalışma koşulları konusunda pazarlık güçleri oldukça zayıf kalmaktadır. İşverenin şikayet etmesi durumunda sınır dışı edilmeye kadar varabilecek yaptırımlarla karşılaşma riski bulunmaktadır. $\mathrm{Bu}$ nedenledir ki GKÜ'lerde düzensiz göçmenlerin daha yoğun bir şekilde bulunmaları ve istihdam edilmeleri mümkündür. Bu ülkelerdeki sermaye birikiminin geldiği aşama itibariyle daha vasıfsız/niteliksiz göçmenlere de iş imkanı sunulmaktadır. Yasal olarak kayıt dışı işçi çalıştırmak yasak olsa bile uygulamada sektörlerin rekabet gücünü arttırmak için işgücü maliyetlerini düşürecek şekilde kayıt dışı iş̧̧i çalıştırmasına da göz yumulmaktadır. Bu durum kayıt dışı göçmen işçi çalıştırılan sektörlerdeki yerli işçilerin maaşları üzerinde aşağ oluşturmakta ve ortalama ücretlerin düşmesine neden olmaktadır. Bunun sonucu olarak da işverenlerin üretimde ortaya çıkan artı değerden işçilere verdikleri pay azalmakta, karşı1lığı ödenmemiş emek zamanı ise artmaktadır. Belirtilen nedenlerle GKÜ’lerde genellikle düzenli göç politikaları ciddi bir şekilde işletilmemektedir. Örneğin ciddi oranda kaçak göçmen işçinin çalıştığ bilinen sektörlerde gerekli denetlemeler yapılmamakta ve göçmenlerin kaderi işverenlerin ellerine birakılmaktadır.

Göç ve GKÜ’lerin kalkınması arasındaki bir diğer ilişki ise göçmen dövizleridir. Göç veren ülkelere yurtdışındaki göçmen vatandaşlarından aktarılan dövizler ciddi boyutlara ulaşmıştır. $\mathrm{Bu}$ 
dövizlerin miktarının kayıtlarda belirtilenden çok daha fazla olduğu tahmin edilmektedir. GKÜ'lere döviz girişi bu ülkelerin sanayileşmek için ihtiyaç duyduğu döviz formundaki sermayeyi sağlayacağı için sermaye birikim sürecine katkı sağlamaktadır. Ayrıca EKÜ'lerin, GKÜ’lere satacakları mamul mallar için efektif talep oluşturarak karlarının realize olmasını sağlamaktadır.

Sonuç olarak göçe küresel yaklaşım bağlamında oluşturulan göç yönetişimi EKÜ’lerin sermaye birikim süreçlerinin ihtiyaçlarına yönelik olarak düzenli göçün kolaylaştırılmasını hedeflerken, GKÜ’lerin düzensiz göçü engelleme noktasında etkin rol almalarını talep etmektedir. Her ne kadar göçe küresel yaklaşım düzenli göçü özendirip, düzensiz göçü ortadan kaldırmayı hedeflese de her ülke kendi birikim sürecinin ihtiyaçlarına bağlı olarak göç yönetimini şekillendirmektedir. Geçmişte esnek göç politikaları uygulayan EKÜ'ler, sermaye birikimlerinin geldiği aşama itibariyle göç politikasını düzenli ve planlı hale getirmişlerdir. Demografik yapılarındaki değişim de bu durumu desteklemektedir. Çalışmanın sınırlılıkları bağlamında olgusal alan dar tutulmuştur ancak çalışmada ortaya koyulan sermaye birikiminin tarihselliği içinde göç politikalarının değerlendirilmesi farklı ülke örnekleri üzerinden başka çalışmalarla geliştirilebilecektir.

\section{Kaynakça}

Böhning, W.R. (1984). Studies in International Labour Migration, Londra: Macmillan; New York: St. Martin's Press.

Castles, S. ve Miller, M.J. (2008). Göçler Çă̆ı Modern Dünyada Uluslararası Göç Hareketleri. İstanbul: Bilgi Üniversitesi Yayınları

Castles, S. ve Kosack, G., (1985). Immigrant Workers and Class Structure in Western Europe, Oxford: Oxford University Press

Cebeci, A. (2018) Göçmen Emeği ve Sermaye Birikimine Etkileri: Suriyeli Sı̆̆ınmacıların İstihdamı, Şanlıurfa Örneği. Göç Konferansı Seçilmiş̧ Bildiriler Kitabı (61-72) Transnational Press London

Cohen, R. (1987). The New Helot: Migrants in the International Division of Labour, Avebury: Aldershot.

Fawcett, J.T. ve Arnold, F. (1987). Explaining Diversity: Asian and Pacific Immigration Systems, J.T. Fawcett ve B.V. Cario (Ed.). Pacific Bridges: The new Immigration from Asia and the Pacific Islands, New York: Center for Migration Studies. https://doi.org/10.1111/j.2050411x.1987.tb00971.x

Hollifield, J.F. (2000). The Politics of International Migration: How Can We "Bring the State Back in?", C.B. Brettel ve J.F. Hollifield (Ed.). Migration Theory: Talking Across Disciplines, New York ve Londra: Routledge. https://doi.org/10.2458/v8i1.21596

Kaya, A. (2016) İslam, Göç ve Entegrasyon: Güvenlikleştirme Çağl, İstanbul: Bilgi Üniversitesi Yayılar1. https://doi.org/10.12658/d0157

Mitchell, C. (1989) International Migration, International Relations and Foreign Policy. International Migration Review, Special Slver Anniversary Issue, 23:3. https://doi.org/10.1177/019791838902300315

Samur, H. (2008). Avrupa Birliği’nde Göçe Yönelik Küresel Yaklaşım. Uluslararası İnsan Bilimleri Dergisi, Cilt:5, Say1:2

Sassen, S. (1988). The Rise of Global Cities and the New Labor Demand In The Mobility of Labour and Capital (126-170), Cambridge: Cambridge University Press. 
Elektronik Kaynaklar:

European Commission, "Global Approach to Migration and Mobility", http://ec.europa.eu/homeaffairs/what-we-do/policies/international-affairs/global-approach-to-migration.

European Commission, "European Agenda on Migration", http://ec.europa.eu/home-affairs/whatwe-de/policies/european-agenda-migration_en

International Organisation for Migration, "Migration and the 2030 Agenda" http://unitedkingdom.iom.int/sites/default/files/oublication/Migration-and-the\%20-2030Agenda.pdf

International Organisation for Migration, "World Migration Report 2020" https://publications.iom.int/system/files/pdf/wmr_2020.pdf

UNDP, Sustainable Development Goals for 2030, http://www.undp.org/content/undp/en/home/sustainable-development-goals.html https://doi.org/10.1811/9789284419401 